\title{
FAKTOR RISIKO YANG BERHUBUNGAN DENGAN KEJADIAN IKTERUS NEONATORUM PADA BAYI BARU LAHIR
}

\author{
Rully Fatriani \\ Akademi Kebidanan Panca Bhakti Bandar Lampung, Indonesia \\ *E-mail: rully.fatriani@pancabhakti.ac.id
}

\begin{abstract}
Abstrak
Ikterus neonatorum merupakan masalah kesehatan yang sering ditemukan di antara bayi baru lahir (BBL) pada minggu pertama kehidupannya, jika tidak ditangani sejak dini dapat berakibat fatal bahkan kematian. Penelitian ini bertujuan untuk mengetahui faktor risiko yang berhubungan dengan kejadian ikterus neonatorum pada BBL. Penelitian yang bersifat analitik korelatif dengan pendekatan cross sectional ini dilakukan terhadap 188 BBL, diambil dengan sistematik random sampling. Data diperoleh dari rekam medik dan dianalisis menggunakan uji Chi-square. Hasil penelitian diperoleh $82(43,6 \%)$ BBL mengalami ikterus neonatorum, dengan $42(71,2 \%)$ $\mathrm{BBL}$ dari $59 \mathrm{BBL}$ dengan riwayat persalinan induksi oksitosin mengalami ikterus neonatorum, $24(68,6 \%) \mathrm{BBL}$ dari $35 \mathrm{BBL}$ prematur mengalami ikterus neonatorum dan $48(35,3 \%) \mathrm{BBL}$ dari $136 \mathrm{BBL}$ yang diberi ASI mengalami ikterus neonatorum. Kesimpulan penelitian ini yaitu ikterus neonatorum lebih berpeluang terjadi pada BBL dengan riwayat persalinan induksi oksitosin, BBL prematur dan BBL yang diberi ASI. Petugas kesehatan yang berwenang diharapkan meminimalkan tindakan induksi oksitosin dan melakukan perawatan intensif sesuai prosedur pada BBL.
\end{abstract}

Kata Kunci : induksi oksitosin, prematuritas, pemberian ASI, ikterus neonatorum

\begin{abstract}
Neonatal jaundice is a health problem that is often found among newborns in the first week of life, if not treated early can be fatal and even death. This study aims to determine the risk factors associated with the incidence of neonatal jaundice in newborns. This correlative analytic study with cross sectional approach was conducted on 188 newborns, taken by systematic random sampling. Data obtained from medical records and analyzed using chi-square test. The results showed 82 (43.6\%) newborns had neonatal jaundice, with 42 (71.2\%) newborns from 59 newborns with a history of oxytocin-induced labor had neonatal jaundice , 24 (68,6\%) newborns from 35 premature newborns had neonatal jaundice and 48 (35,3\%) newborns from 136 breastfed newborns had neonatal jaundice. The conclusion of this study is that neonatal jaundice is more likely to occur in newborns with a history of oxytocin-induced labor, premature newborns and newborns who are breastfed. Authorized health workers are expected to minimize the actions of oxytocin induction and carry out intensive care according to procedures in newborns.
\end{abstract}

Keywords: oxytocin induction, prematurity, breastfeeding, neonatal jaundice 


\section{PENDAHULUAN}

Ikterus neonatorum merupakan masalah kesehatan yang sering ditemukan di antara BBL pada minggu pertama kehidupannya, jika tidak ditangani sejak dini dapat berakibat fatal, dapat berbentuk fisiologis dan sebagian lagi bersifat patologis yang dapat menimbulkan gangguan menetap atau menyebabkan kematian (Rifai, 2003; Sukadi, 2008).

Beberapa faktor risiko untuk mengalami ikterus neonatorum (hiperbilirubinemia) yaitu faktor maternal meliputi : ras, diabetes mellitus, induksi oksitosin, faktor perinatal meliputi : sefal hematoma, memar kulit, faktor neonatus meliputi : prematuritas, faktor genetis, obat-obatan, pemberian ASI, trisomi 21, jenis kelamin laki-laki, kehilangan berat badan, pembentukan tinja lambat (Arvin, 2000).

Banyak BBL, terutama bayi kecil (bayi dengan berat lahir $<2500 \mathrm{~g}$ atau usia gestasi < 37 minggu) mengalami ikterus pada minggu-minggu pertama kehidupannya. Sementara sekitar 1 dari 200 bayi cukup bulan yang menyusu ASI terdapat kenaikan bermakna dari bilirubin tak terkonjugasi antara umur 4 dan 7 hari, mencapai maksimal setinggi $10-30 \mathrm{mg} / \mathrm{dl}$ selama minggu ke-2 sampai ke-3. kemudian lebih dari $30 \%$ dari bayi-bayi tersebut dengan riwayat persalinan induksi oksitosin. (Arvin, 2000).

Angka kelahiran bayi (AKB) di Indonesia diperkirakan mencapai 4,6 juta jiwa per tahun, dengan angka kematian bayi sebesar 48/1000 kelahiran hidup dengan ikterus neonatorum merupakan salah satu penyebabnya sebesar $6,6 \%$ (Balitbangkes Depkes RI, 2002), insidens ikterus neonatorum pada bayi cukup bulan di beberapa RS pendidikan antara lain RSCM, RS Dr. Sardjito, RS Dr. Soetomo, RS Dr. Kariadi bervariasi dari 13,7\% hingga 85\% (HTA Indonesia, 2010). Sementara AKB di Provinsi Lampung Tahun 2007 berjumlah 468 kasus dengan 29 kasus $(6,2 \%)$ diantaranya disebabkan oleh asfiksia, tetanus neonatorum dan ikterus neonatorum (Dinkes Provinsi Lampung, 2008).

Hasil studi pendahuluan peneliti di RSUD dr. A. Dadi Tjokrodipo Bandar Lampung, diketahui dari data 10 besar penyakit pada BBL, ikterus menempati urutan ke 5 pada Tahun 2010 dari bulan April sampai dengan bulan Desember terdapat 49(15,61\%) BBL dengan ikterus neonatorum, sementara pada Tahun 2011 dari bulan Januari sampai dengan bulan Mei terdapat $56(21,21 \%)$ BBL dengan ikterus neonatorum, terjadi kenaikan yaitu $5,60 \%$ kasus ikterus neonatorum. 
Diketahui bahwa $43 \%$ dengan persalinan riwayat induksi oksitosin $21 \%$ bayi prematur 26\% menyusui ASI.

Menelaah fenomena diatas, maka peneliti tertarik untuk meneliti tentang faktor risiko yang berhubungan dengan kejadian ikterus neonatorum pada BBL.

\section{METODOLOGI}

Penelitian kuantitatif ini bersifat analitik korelatif menggunakan desain cross sectional. Penelitian ini dilakukan di RSUD dr. A. Dadi Tjokrodipo Bandar Lampung Bulan Mei - Juli Tahun 2011.

Populasi dalam penelitian ini adalah seluruh bayi baru lahir di RSUD Dr. A. Dadi Tjokrodipo Bandar Lampung Tahun 2010 sampai bulan Juli Tahun 2011 yaitu sebanyak 700 BBL. Penarikan sampel menggunakan systematice random sampling yaitu sebanyak 188 BBL. Data diperoleh dari rekam medik dan dianalisis menggunakan uji Chi-Square

\section{HASIL}

\section{Analisis Data Univariat}

Berdasarkan hasil penelitian yang dilakukan penulis terhadap 188 BBL, maka diperoleh hasil sebagai berikut :
Tabel 1. Distribusi Frekuensi Ikterus Neonatorum

\begin{tabular}{ccc}
\hline $\begin{array}{c}\text { Ikterus } \\
\text { Neonatorum }\end{array}$ & Frekuensi & Presentase \\
\hline Ya & 82 & $43,6 \%$ \\
\hline Tidak & 106 & $56,4 \%$ \\
\hline Jumlah & 188 & $100 \%$ \\
\hline
\end{tabular}

Berdasarkan tabel 1 menunjukkan bahwa lebih dari sebagian responden tidak mengalami ikterus neonatorum yaitu sebanyak $106(56,4 \%)$ dari 188 BBL.

Tabel 2. Distribusi Frekuensi Riwayat Induksi Oksitosin Pada BBL

\begin{tabular}{ccc}
\hline $\begin{array}{c}\text { Induksi } \\
\text { Oksitosin }\end{array}$ & Frekuensi & Presentase \\
\hline Ya & 59 & $31.4 \%$ \\
\hline Tidak & 129 & $68.6 \%$ \\
\hline Jumlah & 188 & $100 \%$ \\
\hline
\end{tabular}

Berdasarkan tabel 2 diketahui bahwa sebagian besar responden tidak dilakukan induksi oksitosin saat persalinan yaitu sebanyak $129(68,6 \%)$ dari 188 BBL.

Tabel 3. Distribusi Frekuensi Prematuritas

\begin{tabular}{ccc}
\hline Prematuritas & Frekuensi & Presentase \\
\hline Ya & 35 & $18.6 \%$ \\
\hline Tidak & 153 & $81.4 \%$ \\
\hline Jumlah & 188 & $100 \%$ \\
\hline
\end{tabular}

Berdasarkan tabel 3 menunjukkan bahwa sebagian besar responden dilahirkan 
dengan tidak prematur yaitu sebanyak 153

$(81,4 \%)$ dari $188 \mathrm{BBL}$.

Tabel 4. Distribusi Frekuensi Pemberian ASI

\begin{tabular}{ccc}
\hline $\begin{array}{c}\text { Pemberian } \\
\text { ASI }\end{array}$ & Frekuensi & Presentase \\
\hline Ya & 136 & $72.3 \%$ \\
\hline Tidak & 52 & $27.7 \%$ \\
\hline Jumlah & 188 & $100 \%$ \\
\hline
\end{tabular}

Berdasarkan tabel 4 diketahui

bahwa sebagian besar responden diberikan
ASI yaitu sebanyak $136(72,3 \%)$ dari 188 BBL.

\section{Analisis Data Bivariat}

Analisis ini digunakan dengan tujuan untuk mengetahui hubungan antara faktor risiko dengan kejadian ikterus neonatorum pada BBL. Berikut akan disajikan hasil perhitungan dengan menggunakan Chi square.

Tabel 5. Distribusi Hubungan Induksi Oksitosin dengan Kejadian Ikterus Neonatorum pada BBL

\begin{tabular}{|c|c|c|c|c|c|c|c|c|}
\hline \multirow{3}{*}{$\begin{array}{l}\text { Induksi } \\
\text { Oksitosin }\end{array}$} & \multicolumn{4}{|c|}{ Diagnosa } & & & \multirow{3}{*}{ P Value } & \multirow{3}{*}{$\begin{array}{l}\text { OR } \\
(95 \% \mathrm{CI})\end{array}$} \\
\hline & \multicolumn{2}{|c|}{ Ikterus } & \multicolumn{2}{|c|}{ Tidak Ikterus } & \multicolumn{2}{|c|}{ Total } & & \\
\hline & $\mathrm{n}$ & $\%$ & $\mathrm{n}$ & $\%$ & $\mathrm{~N}$ & $\%$ & & \\
\hline Induksi & 42 & 71,2 & 17 & 28,8 & 59 & 100 & & \\
\hline Tidak & 40 & 31,0 & 89 & 69,0 & 129 & 100 & 0,000 & 5,497 \\
\hline Induksi & & & & & & & & $(2,8-10,8)$ \\
\hline Total & 82 & 43,6 & 106 & 56,4 & 188 & 100 & & \\
\hline
\end{tabular}

Berdasarkan tabel 5 diketahui bahwa ada 42 $(71,2 \%)$ responden dari 59 responden yang dilakukan induksi oksitosin mengalami ikterus, sedangkan ada $40(31,0 \%)$ dari 129 responden yang tidak dilakukan induksi oksitosin mengalami ikterus. Hasil uji Chi square diperoleh nilai $p$ value 0,000 . Karena $p$ $=0,000<0.05$ maka menunjukkan adanya hubungan antara induksi oksitosin dengan kejadian ikterus neonatorum pada BBL. Hasil analisis diperoleh pula nilai $\mathrm{OR}=5,497$, artinya persalinan dengan induksi oksitosin mempunyai peluang 5,5 kali untuk terjadi ikterus neonatorum dibandingkan dengan yang tidak di induksi oksitosin. 
Tabel 6. Distribusi Hubungan Prematuritas dengan Kejadian Ikterus Neonatorum pada BBL

\begin{tabular}{|c|c|c|c|c|c|c|c|c|}
\hline \multirow{3}{*}{ Prematuritas } & \multicolumn{4}{|c|}{ Diagnosa } & & & \multirow{3}{*}{ P Value } & \multirow{3}{*}{$\begin{array}{l}\text { OR } \\
\qquad(95 \% \mathrm{CI})\end{array}$} \\
\hline & \multicolumn{2}{|c|}{ Ikterus } & \multicolumn{2}{|c|}{ Tidak Ikterus } & \multicolumn{2}{|c|}{ Total } & & \\
\hline & $\mathrm{n}$ & $\%$ & $\mathrm{~N}$ & $\%$ & $\mathrm{~N}$ & $\%$ & & \\
\hline Prematur & 24 & 68,6 & 11 & 31,4 & 35 & 100 & & \\
\hline Tidak & 58 & 37,9 & 95 & 62,1 & 153 & 100 & 0,002 & 3,574 \\
\hline Prematur & & & & & & & & $1,6-7,8$ \\
\hline Total & 82 & 43,6 & 106 & 56,4 & 188 & 100 & & \\
\hline
\end{tabular}

Berdasarkan tabel 6 diketahui bahwa ada $24(68,6 \%)$ responden dari 35 responden yang premature mengalami ikterus sedangkan ada $58(43,8 \%)$ responden dari 153 responden yang tidak prematur mengalami ikterus. Hasil uji chi square diperoleh nilai $p$ value 0,002 .
Karena $p=0,001<0,05$ maka ini menunjukkan adanya hubungan antara prematuritas dengan kejadian ikterus neonatorum pada BBL. Hasil analisis diperoleh pula nilai $\mathrm{OR}=3,574$, artinya bayi prematur mempunyai peluang 3,6 kali untuk terjadi ikterus neonatorum dibandingkan dengan tidak prematur.

Tabel 7. Distribusi Hubungan Pemberian ASI dengan Kejadian Ikterus Neonatorum pada BBL

\begin{tabular}{|c|c|c|c|c|c|c|c|c|}
\hline \multirow{3}{*}{ Pemberian ASI } & \multicolumn{4}{|c|}{ Diagnosa } & \multirow{2}{*}{\multicolumn{2}{|c|}{ Total }} & \multirow{3}{*}{ P Value } & \multirow{3}{*}{$\begin{array}{c}\text { OR } \\
(95 \% \mathrm{CI})\end{array}$} \\
\hline & \multicolumn{2}{|c|}{ Ikterus } & \multicolumn{2}{|c|}{ Tidak Ikterus } & & & & \\
\hline & $\mathrm{n}$ & $\%$ & $\mathrm{n}$ & $\%$ & $\mathrm{n}$ & $\%$ & & \\
\hline Diberi ASI & 48 & 35,3 & 88 & 64,7 & 136 & 100 & & \\
\hline $\begin{array}{l}\text { Tidak diberi } \\
\text { ASI }\end{array}$ & 34 & 65,4 & 18 & 34,6 & 52 & 100 & \multirow[t]{2}{*}{0,000} & $\begin{array}{c}0,29 \\
0,1-0,6\end{array}$ \\
\hline Total & 82 & 43,6 & 106 & 56,4 & 188 & 100 & & \\
\hline
\end{tabular}

Berdasarkan tabel 7 diketahui bahwa ada $48(35,3 \%)$ responden dari 136 responden yang diberi ASI mengalami ikterus, sedangkan ada $34(65,4 \%)$ responden dari 52 responden yang tidak diberi ASI mengalami ikterus. Hasil uji chi square diperoleh nilai $p$ value 0,000 . Karena $p=$ $0,000<0,05$ maka menunjukkan adanya hubungan antara pemberian ASI dengan kejadian ikterus neonatorum pada BBL. Dari hasil analisis diperoleh nilai $\mathrm{OR}=$ 0,29, artinya bayi yang diberi ASI mempunyai peluang 0,3 kali untuk terjadi ikterus neonatorum dibandingkan dengan tidak diberi ASI. 


\section{PEMBAHASAN}

\section{Ikterus Neonatorum}

Hasil analisis data univariat dari $188 \mathrm{BBL}$ diperoleh frekuensi bayi dengan Ikterus Neonatorum sebanyak $82(43,6 \%)$ BBL, sedangkan frekuensi bayi yang tidak ikterus neonatorum sebanyak 106 (56,4\%) BBL. Hasil ini menunjukkan tingginya kejadian ikterus neonatorum pada BBL.

Beberapa faktor risiko untuk mengalami ikterus neonatorum (hiperbilirubinemia) yaitu faktor maternal meliputi : ras, diabetes mellitus, induksi oksitosin, faktor perinatal meliputi : sefal hematoma, memar kulit, faktor neonatus meliputi : prematuritas, faktor genetis, obat-obatan, pemberian ASI, trisomi 21, jenis kelamin laki-laki, kehilangan berat badan, pembentukan tinja lambat (Arvin, 2000).

Ikterus adalah diskolorisasi kulit, membran mukosa dan sklera akibat peningkatan bilirubin indirek > $2 \mathrm{mg} / \mathrm{dl}$. Peningkatan kadar bilirubin indirek > $5 \mathrm{mg} / \mathrm{dl}$ selalu ditemukan pada hampir setiap BBL dalam minggu pertama kehidupannya. Hiperbilirubinemia indirek dijumpai pada $60 \%$ bayi cukup bulan dan $80 \%$ bayi kurang bulan (Glasgow, 2000).

Setiap bayi dengan ikterus harus mendapatkan perhatian, terutama apabila ikterus ditemukan dalam 24 jam pertama kehidupan bayi atau bila kadar bilirubin meningkat lebih dari $5 \mathrm{mg} / \mathrm{dl}$ dalam 24 jam. Proses hemolisis darah, infeksi berat, ikterus yang berlangsung lebih dari 1 minggu serta bilirubin direk lebih dari 1 $\mathrm{mg} / \mathrm{dl}$ juga merupakan keadaan yang menunjukkan kemungkinan adanya ikterus patologis. Dalam keadaan tersebut penatalaksanaan ikterus harus dilakukan sebaik-baiknya agar akibat buruk ikterus dapat dihindarkan. (Aminullah, 2000)

Berbagai teknik diagnostik telah digunakan untuk menilai ikterus pada BBL. Pengukuran bilirubin serum dianggap sebagai metode yang paling terpercaya, tetapi memiliki keterbatasan dalam hal peralatan dan biaya. Pemeriksaan langsung secara visual tidak dapat dipercaya sepenuhnya dan dapat menyebabkan kesalahan diagnosis. Metode pemeriksaan non inovasif lain seperti transcutaneus bilirubinometry (TcB) merupakan alternatif pemeriksaan (skrining) pengukuran bilirubin serum. Sampai saat ini belum ada keseragaman tatalaksana ikterum neonatorum di Indonesia. Kadar serum bilirubin untuk memulai masing-masing jenis terapi (Terapi Sinar, Transfusi Tukar, ObatObatan) masih menjadi pertanyaan. Di satu sisi, terapi yang berlebihan berarti menyia- 
nyiakan sumber daya yang tidak perlu. (HTA Indonesia,2010).

Oleh karena itu, petugas kesehatan bersama dengan keluarga BBL hendaknya benar-benar memperhatikan bayinya terutama pada minggu pertama kehidupannya, memantau perkembangan bayi dengan seksama sehingga bila ditemukan kelainan atau komplikasi akibat persalinan yang berisiko terjadinya ikterus neonatorum segera dapat di ketahui dan dapat ditangani sesuai dengan prosedur.

\section{Induksi Oksitosin}

Hasil analisis data univariat didapatkan bahwa dari 188 (100\%) BBL terdapat 59 $(31,4 \%)$ BBL dilakukan induksi oksitosin saat persalinan, dan $129(68,6 \%)$ BBL tidak dilakukan induksi oksitosin saat persalinan.

Berdasarkan hasil penelitian diketahui bahwa penyebab dilakukannya induksi oksitosin jika ditinjau dari riwayat persalinan yang terjadi di RSUD. Dr. A. Dadi Tjokrodipo Bandar Lampung disebabkan ibu yang akan melahirkan tersebut rata-rata adalah ibu dengan kehamilan risiko tinggi dan tidak dapat dilahirkan secara normal sehingga dirujuk oleh bidan dan atau puskesmas diantaranya seperti kehamilan lewat waktu, Ketuban
Pecah Dini (KPD), kehamilan dengan hipertensi, Pre Eklamsi Berat, dll. Adanya risiko tinggi dan terpenuhi indikasi untuk dilakukan induksi, dan bayi harus segera dilahirkan maka persalinan dengan induksi dilakukan untuk mempercepat kelahiran.

Induksi persalinan (oksitosin) adalah upaya untuk melahirkan janin menjelang aterm dalam keadaan belum terdapat tanda-tanda persalinan (belum inpartu), dengan kemungkinan janin dapat hidup diluar kandungan (umur diatas 28 minggu). Dengan induksi persalinan bayi sudah dapat hidup di luar kandungan. Ini upaya untuk menyelamatkan janin dari pengaruh buruk jika janin masih dalam kandungan (Manuaba, 2007).

Sejumlah indikasi yang harus dipenuhi diantaranya yaitu : indikasi janin berupa kehamilan lewat waktu, ketuban pecah dini (KPD), kelainan congenital, IUFD. Indikasi ibu berupa penyakit hipertensi, komplikasi kehamilan seperti Preeklampsia atau eklampsia (Manuaba, 2007).

Oleh karena itu, induksi persalinan dengan oksitosin sebaiknya tidak menjadi rutinitas namun hal ini merupakan tindakan yang perlu dilakukan bila telah terpenuhi indikasi-indikasinya. Sebaiknya, sebelum memutuskan untuk melakukan induksi 
petugas kesehatan benar-benar telah mengkaji pasien sehingga tindakan yang dilakukan tidak berdampak pada komplikasi-komplikasi akibat induksi persalinan.

\section{Prematuritas}

Hasil analisis data univariat didapatkan bahwa dari 188 (100\%) BBL terdapat 35 $(18,6 \%)$ BBL dilahirkan dengan prematur, dan $153(81,4 \%)$ BBL dilahirkan tidak prematur.

Berdasarkan hasil penelitian diketahui bahwa sebagian besar BBL yang dilahirkan dengan prematur disebabkan beberapa faktor diantaranya kehamilan ganda, KPD, jarak kehamilan yang terlalu dekat, ibu dengan hipertensi dan lain lain.

Faktor predisposisi terjadinya kelahiran prematur antara lain : faktor ibu: riwayat kelahiran prematur sebelumnya, perdarahan antepartum, malnutrisi, kelainan uterus, hidramnion, penyakit jantung/ penyakit kronik lainnya, hipertensi, umur ibu $<20$ Tahun atau $>35$ Tahun, jarak dua kehamilan yang terlalu dekat, infeksi, trauma dan lain-lain; faktor janin : cacat bawaan, kehamilan ganda, hidramnion, ketuban pecah dini; keadaan sosial ekonomi yang rendah; kebiasaan : pekerjaan yang melelahkan, merokok; faktor yang tidak diketahui sebabnya (Prawirohardjo, 2009).

Faktor risiko lain yang berperan dalam terjadinya persalinan prematur adalah: Kehamilan usia muda ( usia ibu $<18$ Tahun), pemeriksaan kehamilan yang tidak teratur, golongan usia ekonomi lemah, keadaan gizi yang kurang, penyalahgunaan obat (Prawirohardjo, 2009).

Untuk menghindari persalinan prematur sebaiknya ibu hamil memeriksakan kandungannya secara rutin, menghindari pekerjaan yang melelahkan disamping itu memenuhi kebutuhan nutrisinya sehingga persalinan prematur dapat dihindarkan.

\section{Pemberian ASI}

Hasil analisis data univariat didapatkan bahwa dari 188 (100\%) BBL terdapat 136 (72,3\%) BBL yang diberikan ASI, dan 52 $(27,7 \%)$ BBL tidak diberikan ASI oleh ibunya.

Berdasarkan hasil penelitian diketahui bahwa masih banyak BBL yang belum mendapatkan ASI, diduga penyebab tidak diberikannya ASI oleh ibu responden karena keterbatasan mobilisasi seperti ibu dengan post Sectio Cesarea atau persalinan yang berat, disamping itu disebabkan kurangnya pengetahuan ibu tentang pentingnya ASI terutama 
pemberiannya secara eksklusif dimana diketahui bahwa ibu responden berlatar belakang pendidikan SD, sehingga meskipun mayoritas diantara mereka memberikan ASI kepada bayinya namun tidak secara eksklusif, ASI belum diberikan sesuai dengan jumlah yang dibutuhkan bayi.

ASI adalah makanan alamiah untuk bayi yang mengandung nutrisi - nutrisi dasar dan elemen dengan jumlah yang sesuai untuk pertumbuhan bayi. ASI adalah makanan terbaik yang dapat diberikan oleh seorang ibu pada anak yang baru dilahirkannya (Prawirohardjo, 2009).

Manfaat utama pemberian ASI eksklusif adalah: sebagai nutrisi terbaik, meningkatkan daya tahan tubuh, meningkatkan kecerdasan, meningkatkan jalinan kasih sayang antara ibu dan anak. (Roesli, 2001).

Petugas kesehatan sebaiknya aktif memberikan penyuluhan kepada ibu dan keluarganya tentang pentingnya manfaat ASI eksklusif agar dapat membantu ibu untuk memberikan ASI secara eksklusif serta mengatasi keterbatasan mobilsasinya dengan senantiasa mendampingi mereka pada hari-hari pertama pasca persalinan.

\section{Hubungan Antara Induksi Oksitosin dengan Kejadian Ikterus Neonatorum}

Hasil analisis data bivariat dengan uji chi square diperoleh nilai $p$ value $0,000 \cdot p$ value $=0,000<0,05$, menunjukkan adanya hubungan antara induksi oksitosin dengan kejadian ikterus neonatorum pada BBL.

Berdasarkan hasil penelitian, diketahui bahwa salah satu penyebab terjadinya ikterus neonatorum adalah induksi persalinan, dalam hal ini induksi oksitosin. Induksi oksitosin sangat mungkin berdampak terjadinya ikterus neonartorum karena diketahui bahwa zat-zat kimia dapat mengurangi ikatan bilirubin sehingga bayi mengalami ikterus.

Ikterus yang biasanya menetap sesudah minggu pertama kehidupan dan bilirubinnya meningkat ialah bilirubin tidak langsung. Hal ini disebabkan oleh adanya obat atau zat kimia yang mengurangi ikatan bilirubin tidak langsung pada albumin, salah satunya dengan induksi oksitosin. Kandungan dialamnya mempunyai afinitas yang lebih besar terhadap albumin (Prawirohardjo, 2009).

Oleh sebab itu, persalinan dengan induksi oksitosin lebih berisiko terhadap kejadian ikterus neonatorum. Dimana Ikterus 
Neonatorum merupakan salah satu penyebab masih tingginya angka kematian BBL. Sehingga diharapkan untuk tidak menginduksi pada saat persalinan kecuali atas indikasi yang sesuai dengan prosedur yang berlaku.

\section{Hubungan Prematuritas dengan}

\section{Kejadian Ikterus Neonatorum}

Berdasarkan hasil penelitian diketahui bahwa dari 35 responden dengan prematuritas terdapat 24 responden $(68,6 \%)$ mengalami ikterus. Hasil analisis data bivariat dengan uji chi square diperoleh nilai $p$ value 0,001 . Karena $p=$ $0,002<0,05$ maka menunjukkan adanya hubungan antara prematuritas dengan Kejadian ikterus neonatorum pada BBL. Hal ini menunjukkan bayi prematur (masa gestasi 20 sampai dengan $<37$ minggu) berisiko lebih tinggi terjadi ikterus neonatorum (Fraser \& Cooper,, 2009).

Ikterus neonatorum pada bayi prematur disebabkan oleh penghancuran sel darah merah yang berlebihan, hati dan gastrointestinal yang belum matang. Maturasi hati postnatal pada bayi prematur menjadikan proses bilirubin uptake dan konjugasi menjadi lebih lambat. Kadar bilirubin meningkat lebih awal, kemudian mencapai puncak (5-7 hari)dan tetap meningkat lebih lama. Selain itu keterlambatan dalam memberikan makanan enteral dalam pengelolaan klinis bayi baru lahir prematur yang sakit dapat membatasi motalitas usus dan kolonisasi bakteri yang mengakibatkan peningkatan sirkulasi bilirubin enterohepatik lebih lanjut (Cohudhury et al, 2011).

Metabolisme bilirubin bayi baru lahir berada dalam transisi dari stadium janin yang selama waktu tersebut plasenta merupakan tempat utama eliminasi bilirubin yang larut lemak, ke stadium dewasa yang selama waktu tersebut bentuk bilirubin terkonjugasi yang larut air diekskresikan dari sel hati kedalam sistem biliaris dan kemudian kedalam saluran pencernaan, Hiperbilrubinemia tak terkonjugasi dapat disebabkan oleh setiap faktor yang menambah beban bilirubin untuk dimetabolisme oleh hati seperti prematuritas (Fraser \& Cooper,, 2009).

Pada bayi prematur kenaikan kadar bilirubin serum cenderung sama atau sedikit lebih lambat daripada kenaikan bilirubin pada bayi cukup bulan tetapi jangka waktunya lebih lama yang biasanya mengakibatkan kadar yang lebih tinggi. Puncaknya pada hari ke 4 dan hari ke 7 dan gambarannya bergantung pada waktu yang diperlukan bayi prematur untuk mencapai mekanisme matur dalam metabolisme dan ekskresi biliruin. Biasanya pada puncak $8-12 \mathrm{mg} / \mathrm{dl}$ tidak 
dicapai sebelum hari ke 5 sampai hari ke 7 dan ikterus jarang diamati sesudah hari ke 10 (Fraser \& Cooper,, 2009).

Dalam menegakkan diagnosis ikterus neonatorum menggunakan pemeriksaan bilirubin serum dalam darah untuk menentukan intervensi lebih lanjut. Beberapa hal perlu dipertimbangkan dalam pelaksanaan pemeriksaan serum bilirubin ini merupakan tindakan invasif yang dapat meningkatkan angka morbiditas neonatus.Umumnya yang diperksa adalah bilirubin total (Fraser \& Cooper, 2009).

Risiko ikterus dihubungkan dengan kejadian kernikterus (ensefalopati bilirubin) pada kadar bilirubin indirek serum yang tinggi. Kadar bilirubin serum yang disertai dengan kern ikterus sebagai bergantung pada etiologi ikterus. Kernikterus berkembang pada kadar bilirubin yang lebih rendah pada bayi prematur. Kekhawatiran tentang hiperbilirubinemia tak terkonjugasi pada neonatus prematur adalah terjadinya kernikterus. Pengendapan pigmen kuning oleh bilirubin diganglia basalis dan hipotalamus merupakan petunjuk terjadinya degenerasi berat ditempat ini. Pada bayi aterm dengan kadar bilirubin tinggi dan tanpa faktor risiko lainnya sangat kecil kemungkinan untuk terjadinya kern ikterus (Fraser \& Cooper, 2009).

Bayi prematur yang bertahan hidup, kemudian memperlihatkan spastisitas inkoordinasi otot dan retardasi mental dengan derajat bervariasi. Terdapat korelasi positif antara kern ikterus dan kadar bilirubin tidak terkonjugasi diatas 18-20 mg/dl, walaupun kern ikterus dapat timbul pada konsentrasi yang jauh lebih rendah, terutama pada bayi sangat prematur. Pencegahan yang dapat dilakukan agar tidak terjadi ikterus yaitu dengan melakukan pencegahan pada faktor risiko terjadinya ikterus pada neonatus (Cunningham, 2009).

\section{Hubungan Pemberian ASI dengan Kejadian Ikterus Neonatorum}

Berdasarkan hasil penelitian diketahui bahwa dari 136 responden yang diberi ASI terdapat 48 responden $(35,3 \%)$ mengalami ikterus. Hasil analisis data bivariat dengan uji chi square diperoleh nilai signifikansi $p$ 0,000. Karena $p=0,000<0,05$ maka menunjukkan adanya hubungan antara pemberian ASI dengan kejadian ikterus neonatorum pada BBL.

Terdapat dua jenis ikterus neonatorum terkait ASI; (1.) Breast-feeding-associated jaundice, diketahui disebabkan oleh 
pemberian ASI yang tidak adekuat dan buruknya intake cairan yang menyebabkan starvation dan tertundanya pengeluaran mekonium pada neonatus, hal tersebut akan meningkatkan sirkulasi enterohepatik. (2) Breast milk jaundice, keadaan dimana terjadi peningkatan absorbsi bilirubin di dalam usus (sirkulasi enterohepatik) karena aktivitas enzim $\beta$ glukoronidase yang bisa terdapat pada ASI yang abnormal (Gomella et al, 2009).

Kecenderungan peningkatan frekuensi hiperbilirubinemia pada bayi cukup bulan yang mendapat ASI dibandingkan dengan bayi yang mendapat susu buatan. Kadar bilirubin serum pada hari 3-4 diatas 12 $\mathrm{mg} / \mathrm{dl}$ dilaporkan antara $11 \%$ sampai $26 \%$. Pada kelompok bayi yang mendapat ASI dengan hiperbilirubinemia ini, kadar bilirubin direk, kadar $\mathrm{Hb}$, jumlah retikulosit, hemogram, keseluruhannya dalam batas normal (Arvin, 2000).

Ikterus pada bayi yang mendapat ASI (breast milk jaundice) berkaitan dengan ekskresi pregnane $3 \alpha, 20 \beta$ diol ibu ke dalam ASI. Steroid ini menghambat konjugasi bilirubin dengan menghambat aktivitas glukuronil transferase. Susu sapi dan manusia tampaknya menghambat reabsorpsi bilirubin bebas, sedangkan susu dari ibu dengan anak yang mengalami ikterus tidak, dan bahkan mungkin meningkatkan reabsopsi. Pada ikterus ASI, kadar bilirubin serum meningkat mulai sekitar hari keempat setelah lahir hingga maksimum pada 15 hari. Apabila menyusui dilanjutkan, kadar tinggi akan menetap selama 10 hingga 14 hari lagi dan secara perlahan menurun dalam beberapa minggu. Kejadian kernikterus akibat fenomena ini (Laveno, 2009).

Bila diitinjau dari karakteristik ibu maka seharusnya, BBL tersebut dapat memperoleh ASI yang cukup karena mayoritas ibu bekerja sebagai ibu rumah tangga. Namun dilain pihak kemungkinan tidak diberikannya ASI disebabkan faktor lain seperti BBL dengan ibu post $\mathrm{SC}$, atau rendahnya keterikatan ibu dengan bayi sehingga ibu dan bayi sangat jarang berinteraksi dan rendahnya pengetahuan ibu tentang besarnya manfaat ASI menjadi salah satu penghambat sehingga ibu tidak memberikan ASI kepada bayinya secara eksklusif.

Oleh sebab itu, bayi sebaiknya diberikan ASI secara eksklusif, sehingga meskipun timbul ikterus pada minggu pertama kehidupannya, bayi tersebut dapat segera kembali sehat dan bilirubin yang meningkat dapat kembali normal. Ibu sebaiknya lebih memberikan perawatan dan penanganan yang intensif pada bayi ikterus dalam hal pemberian ASI. Karena 
ASI pun mengandung antibody yang berguna untuk mencegah masuknya kuman penyakit yang akan menginfeksi tubuh.

\section{KESIMPULAN}

Berdasarkan hasil penelitian dapat disimpulkan bahwa : ikterus neonatorum lebih berpeluang terjadi pada BBL dengan riwayat persalinan induksi oksitosin, BBL prematur dan BBL yang diberi ASI.

Petugas kesehatan yang berwenang diharapkan meminimalkan tindakan induksi oksitosin dan melakukan perawatan intensif sesuai prosedur pada BBL.

\section{KEPUSTAKAAN}

Aminullah, A. (2000). Ikterus dan Hiperbilirubinemia Pada Neonatus. di dalam FKUI. Jakarta: Gaya Baru.

Arvin, B \& Kliegman. (2000). Ilmu Kesehatan Anak Nelson Volume 1. Jakarta: EGC

Balitbangkes Depkes RI. (2002). Survey Kesehatan Rumah Tangga (SKRT). Jakarta: Departemen Kesehatan RI.

Choudhury, P. Bagga, A. Chugh, K. Ramji, S. Gupta, P. (2011). Principles of Pediatrics \& Neonatal Emergencies. Jaypee Brothers
Medical Publishers Pvt. Ltd. 2011.487-508.

Cunningham, FG. (2009). Obstetri Williams. Jakarta: EGC.

Dinas Kesehatan Provinsi Lampung . (2008). Profil Kesehatan Provinsi Lampung Tahun 2007. Dinas Kesehatan Provinsi Lampung.

Fraser, DM. \& Cooper, MA. (2009). Buku Ajar Bidan Myles Edisi 14. Jakarta: EGC.

Glasgow. (2000). Jaundice and Hyperbilirubinemia. In: R.E. Behrman, R. Kliegman, H.B. Jenson, eds. Nelson Textbook of Pediatric, 16 th Edition. Philadelphia: W.B. Saunders Company.

Gomella, TL. Cunningham, MD. Eyal, FG. (2009). Neonatology : Management, Procedures, On-Call Problems, Diseases, and Drugs. McGraw-Hill Education.

HTA Indonesia. (2004). Tata Laksana Ikterus Neonatorum. Jakarta: Departemen Kesehatan RI.

Laveno, KJ. (2009). Obstetri Williams Edisi 21. Jakarta: EGC.

Manuaba, IBG. (2007). Pengantar Kuliah Obstetri. Jakarta: EGC.

Prawirohardjo, S. (2009). Ilmu Kebidanan. Jakarta : Bina Pustaka. 
Rifai, TRFB. (2003). Hiperbilirubinemia.

Dalam: Partini P. Trihono, Asti Praborini, penyunting Pediatrics Update. Jakarta: IDAI Cab. Jakarta.

Roesli, U. (2001). Bayi Sehat Berkat Asi Eksklusif. Jakarta: Elex Media Komputindo.

Sukadi, A. (2008). Hiperbilirubinemia. Dalam: Kosim MS, Yunanto A, Dewi R, Sarosa GI, Usman A, penyunting Buku Ajar Neonatologi. Jakarta: Badan Penerbit IDAI. 